\title{
Perspektiewe op erotiek en seksualiteit in die ou Nabye Ooste
}

\author{
D J Human \\ (Universiteit van Pretoria)
}

\section{ABSTRACT}

Perspectives on erotism and sexuality in the ancient Near East

Sexuality and erotism form an integral part of life. Both these aspects mediate life fulfilling experiences of love. As part of the creation reality sexuality effects a positive power of life. Evidence from the ancient Near East, especially from Egypt, Canaan and Mesopotamia, confirms human's facinasion for and participation in sexual behaviour. In the sexual experience the 'I' transcends the borders of the 'self'. Whether the gods or humans are engaged in this act of heavenly ecstacy, it is evident that life's meaning is captured in this life enriching experience of power, vitality and joy.

\section{INLEIDING}

Om oor erotiek en seksualiteit te praat, is byna soos om oor God of die dood te praat. Jy kry dit nooit heeltemal reg nie. Daarom het mens nie ' $\mathrm{n}$ volle greep daarop nie. Daar bly altyd iets ongesê, onverwoord en onvolledig. Hierdie grootse ervaring van die liefde met sy vele kante en baie gestaltes kan jy eenvoudig nie met enkele beskrywings oopdek nie.

Selfs wanneer die liefde tot vervulling kom in die ervarings van seksualiteit en erotiek is woorde ontoereikend om definisie te gee aan hierdie hemelse ekstase, wat sin, geluk en betekenis aan die lewe gee. Tog help die waagmoed tot " $n$ paar pennestrepe ons om die mooiste lewensgeure van die seksuele te proe en in te asem.

Deur seksualiteit vind 'n mens lewensvervulling. Elkeen kan die seksuele anders beleef, verstaan of met ander inhoude en verwagtinge vul. Seksualiteit is ' $n$ basiese lewensbehoefte wat bevrediging najaag. Dit is deel van die skeppingswerklikheid en 'n postiewe lewenskrag (Frevel \& Wischmeyer 2003:46). Soos die drang om te eet of te drink, is die bevrediging aan seksuele vreugde ' $n$ bron van $\mathrm{krag}$, vitaliteit en lewensgenot. Om as volledige mens na liggaam en gees gesond te bly, moet hierdie behoefte voortdurend vervulling geniet. Daarom word mense altyd deur hul fassinering vir die seksuele aangevuur en ontroer. 
Seksualiteit is meer as net ' $n$ liggaamlike behoefte. Dis ' $n$ versugting na die totale menswees van die 'ander' - ' $n$ intieme soeke na die mooie van liggaam en gees en siel. Momente van hierdie belewenis kom na vore in flitsbeskrywings soos fantasie, invoeling, intelligensie, vitaliteit, kreatiwiteit, intensivering van gevoelens, diepe liefde vir die 'ander', lus, ontspanning, vermoë tot nie-verbale uitdrukking van die self, om oorweldig te word, om jouself oor te gee, spirituele en transenderende geluksbelewenis, en die prysgawe van die self as ' $\mathrm{n}$ soort doodservaring.

In die afsterwe van die 'self' tydens die seksuele ontmoeting word nie net ' $n$ positiewe waardering van die dood geskep nie, maar in hierdie ontmoeting vloei die ervarings van liefde, dood en die religieuse ineen.

By die seksuele eenwording van geliefdes word die 'ek'-grense van die individu opgehef, die 'eie' identiteit lê weerloos bloot en die tyd word tot stilstand gedwing. Die geliefde sterf hier aan hom- of haarself in die oorgawe aan die ander. Hiérdie liefdesdaad skep sterk gevoelens van passie en ontroering, maar ook van wedersydse ondersteuning. Geliefdes dra mekaar in 'n ekstatiese atmosfeer waarin die viering van seksualiteit die liefdespassie omstraal.

Om by die grense van die 'ek' uit te plof in die sagte nabyheid van die geliefde se warm, geurige lewensasem...dit verwoord deels die hemelse ervaring van seksualiteit. Met dit as vertrekpunt, is erotiek die sinlike genot van seksualiteit in beeld, kuns en klank op die teaterverhoog van die lewe. Erotiek is gekultiveerde en sublieme seksualiteit (Haag \& Elliger 1998:108). Dit is ' $n$ dryfveer vir alle lusskeppende handelinge, hetsy liggaamlik, psigies, kunstig of wetenskaplik. Daarom betrek dit die seksuele op die nie-seksuele, veral op die intellektuele en kunssinnige gebiede van die lewe. Vir die-met-die-dood-bedreigde mens skep erotiek nuwe lewensmoontlikhede ${ }^{1}$.

1 Eros, die Griekse god van liefde was, volgens die mitologie, "n oergod aan die begin van die wêreld. Hy was op die lewe gerig en het lewensskeppende kragte gehad. Hy oorwin die dood en versoen teenstrydighede. Eros druk die spanning tussen die werklikheid en die gedroomde (of gedagtemoontlikhede) uit deur altyd na die hoëre te streef en nie tevrede te wees met dit wat bereik is nie. 


\section{VRUGTE VAN DIE LIEFDE}

\subsection{Voorspel}

Tot die antieke wêreld van die Nabye Ooste behoort verskeie tydperke, volke, tale en kulture. Nie almal het die vreugde en hartseer van die liefde, soos uitgebeeld in seksualiteit en erotiek, altyd op die dieselfde manier beskryf en beoefen nie.

Egipte, Kanaän, Sirië en Mesopotamië was 'n kultuur-ruimte waarbinne ons die antieke mense se konsep(te) van seksualiteit en erotiek ontdek. In die liefdeslirieke, omina, ostraka, beswerings- en ritueeltekste, mites, kodekse en ikonografie van hierdie volke, klink die klanke van elke kultuurgroep se beelde, aard, inhoud, klemtone en voorkeure van seksualiteit op. Wetlike en eties gereguleerde oorlewerings lê verstrooi in die kultuurspatsels van die verskillende Nabye Oosterse volke.

Binne hierdie antieke wêreld het die volk Israel tot hul eie verstaan van seksualiteit en erotiek gegroei. Soms het Israel motiewe en gedagtes uit hulle omgewing oorgeneem, maar ander kere protesteer die volk van Jahwe daarteen.

In die ou Nabye Ooste bestaan daar verskeie aspekte van seksualiteit en erotiek. Seksualiteit kom binne en buite die eg $(\text { huwelik? })^{2}$ voor. Daar was hetero- en homoseksualiteit, prostitusie, sodomie, transvestisme, nekrofilie, zoo-filie, en pederastie. Alhoewel hierdie vorme van seksualiteit bestaan het, is dit in verskillende dele van die antieke kultuurruimte(s) en tye op verskeie maniere beoordeel.

Veral in die gode-verhale of mites van die antieke wêreld kom aspekte van menslike seksualiteit na die oppervlak. Antieke mense het die godewêreld as ' $n$ spieëlbeeld van die aardse lewe beskou. Die transendente het in die immanente weerkaats. Wat met die gode gebeur, is eintlik ' $n$ weergawe van die mens, sy/haar gedrag en sy/haar ervarings. Daarom spieël antieke mites hoe mense oor hulle eie seksualiteit gedink en gedoen het.

2 Die begrip 'eg', wat dui op ' $\mathrm{n}$ bepaalde (spesiale) verbintenis tussen man en vrou, word hoofsaaklik in hierdie artikel gebruik. Die term 'huwelik' word eerder vermy om nie die inhoude van hierdie meer moderne konsep op die verhouding wat destyds in die Nabye Ooste bestaan het, oor te dra nie. 
Verhale van Isis, Osiris, Set en Horus in Egipte, of Gilgamesj en Enkidu in Mesopotamië, of Asjera (Isjtar) met haar Baäl (Tammuz/Dumuzi) dwarsoor die antieke wêreld borrel oor van seksualiteit. Menslike geliefdes het hulle soos gode gedra en gode was geliefdes (Berlejung 2001:3ev). Hierdie saak word duidelik uit Egipte wanneer die god $R e$ as geliefde 'broer', en die godin Hator as geliefde 'suster' aangespreek word'. Of selfs wanneer geliefdes soos gode oor die berge huppel en mekaar omhels (Hoogl 2:8), word die skepping ' $\mathrm{n}$ liefdestuin waarin die liefde tot vervulling kom. In hierdie liefdestuin van die lewe is daar heerlike en smaakvolle vrugte om in oorvloed te geniet.

\subsection{Soos eet en drink deel van die lewe}

Soos eet en drink was seksualiteit en erotiek in die ou Nabye Ooste deel van die lewe. Dit het uitdrukking gegee aan mens-wees in sy volheid. Liefde is op ' $n$ besondere manier deur seksualiteit en erotiek uitgedruk.

Liefde was vir die Nabye-Oosterse denke meer as net ' $n$ vlugtige gevoel. Dit het die totale lewensruimte van die mens ingesluit. Natuur, kultuur, asook mense en gode is by die liefde betrek. Dit het beteken dat seksualiteit vanselfsprekend deel van die godsdienstige en profane lewenssfere was.

Soos vandag was mense uit antieke tye emosioneel en liggaamlik by die liefde betrokke. Liefdesgevoelens en fisiese aantrekkingskrag is nie van mekaar geskei nie. As individue mekaar liefhet, het hulle fisiese kontak met mekaar gemaak. Hulle het mekaar omarm, gedruk, gesoen en uiteindelik liggaamlike gemeenskap met mekaar gehad. Verskeie erotiese uitbeeldings uit Egipte en Mesopotamië van liefdes- en godepare kom op reliëfs, terracotta-uitbeeldings, seëls en ander beeldjies voor. Voorbeelde hiervan is voorstellings van Inanna en Dumuzi in Nippur of Amenofet en Hator in Egipte.

3 Met die terme 'broer' en 'suster' is die engste verbintenis tussen die manlike en vroulike geslagte in die Nabye Ooste aangedui. Dit was nie vanweë hulle verwantskap nie, maar in die oordrewe patriargaal gestruktureerde lewe het mans en vroue normaalweg in die openbare samelewing in verskillende groepe beweeg. ' $n$ Broer kon egter sy suster in die openbaar begelei. Hierdie verhouding het nabyheid uitgedruk. In die liefdespoësie word dit as metafore vir die noue band tussen geliefdes gebruik. 


\subsection{Die liggaam - 'n lushof van verleiding}

Die seksuele sug altyd na die liggaam. Die liggaam is en was nog altyd ' $n$ wapen van verleiding - ook in die Nabye Ooste. Met die skoonheid van die liggaam word die aandag van die geliefde vasgevang. Daarmee raak die totale menswees van geliefdes in mekaar verstrengel. Die oog streel die liggaam, die oor vang die fluistering van die liefdesasem op, die neus geniet die heerlike liefdesgeure, die hand betas die skone rondings van sy vorm, en die mond smaak die genot van sy liefdesdrank. So neem die sensuele sensore die liggaam van die 'ander' totaal in besit. Gevoelens van vreugde en verlange is gewek, en dit het tot genot en ekstase gelei.

' $n$ Positiewe waardering van die liggaam kom telkens in antieke tekste na vore. Veral in liefdespoësie, waarin liriese liefdesbeskrywings van gode en geliefdes tot uitdrukking kom, word die liggaam in detail beskryf.

Sedert antieke tye was dit die mens se strewe om die liggaam mooi, aangenaam en perfek te maak. ' $n$ Gesonde, mooi liggaam roep die nabyheid van die 'heilige', die transendente, of die wêreld van die gode op omdat dit die hemelse orde beliggaam. Daarom moet die hele liggaam mooi versier en versorg word (Winter 1983:302-312).

Skoonheidsbehandeling was daarom nie vreemd in die ou Nabye Ooste nie (Est 2:9-12). Argeologiese ontdekkings bevestig die rol wat skoonheidversorging in die samelewing gespeel het. Aangename geure en salfprodukte wat oorspronklik in godsdienstige kultus-ruimtes gebruik is om gode se guns en aandag te wek, is buite die kultus gebruik om erotiese aantrekkingskrag te versterk (Caubet 2001:9-11). Hiermee kom die verweefdheid van religieuse en seksuele ervarings na vore. Hierdie verband tussen godsdiens en seksualiteit word bevestig in die Baäl se paleis verhaal uit Ugarit waar die godin Anat haar mooimaak vir haar geliefde (III, B, reëls 42ev):

"Sy versier haar skoonheid met die purperslak,

wat sy oorsprong in die....see het,

Sy neem haar lier in haar hand,

Sy plaas korale op haar bors,

Sy sing van haar liefde vir die magtigste Baäl" (Gibson 1977:48). 
Afgesien van bekende geurstowwe soos mirre, het mense kosmetiese versierings en juweliersware gebruik om die liggaam of liggaamsdele te versier. Verskillende soorte edelstene, ivoorvoorwerpe, halssnoere, kettinkies, hangertjies en borsspelde is aangewend. Met mooi klere het veral vroue, maar ook mans die liggaam verder opgehelder. Gereelde reiniging deur die liggaam te bad of te was, was gebruiklik. Na hierdie reinigingsproses is dit met olie of geurige salf ingevryf. Sodoende is seksuele genot en liefdesvreugde verhoog.

Om hare te sny, dit op te maak, of te versier, het by mans en vroue voorgekom. Hierdie gebruik het vir sosiale identiteit, etniese gebondenheid en erotiese uitstraling gesorg. 'n Bekende argeologiese beeld uit Bet Shean wys die Egiptiese godin, Hator ${ }^{4}$, as pragtige vrou, met opgesmukte hare en 'n sonskyf tussen 'n paar horings op haar kop. Haar kop is met goud oortrek en sy straal erotiese elegansie uit.

In die verhale oor die liefde van Baäl en Anat uit Ugarit het die godin Anat haar opgetooi en mooi gemaak voordat sy haar 'broer' Baäl, die god van vrugbaarheid, gaan besoek het. Sy het water geskep en haar gewas met die dou van die hemel, met die olie van die aarde en met die reën van haar 'Ruiter-van-die-wolke'. Haar soeke na Baäl word met erotiese opwinding beskryf (Gibson 1977:76-77). Dit is duidelik dat hierdie gode-aktiwiteite of natuurprosesse die seksualiteit van die menslike lewe reflekteer. Dood en lewe, vrugbaarheid en onvrugbaarheid, skoonheid en vreugde lê alles ingebed agter die taal en metafore van die liefdesspel.

\section{4 'n Granaatappel vol beskawing en kultuur}

Veral met betrekking tot beskawing en kultuur het seksualiteit hoë waarde en aansien in die ou Nabye Ooste geniet. Seksuele praktyke was geïntegreer in ' $n$ spektrum van kultuur-aktiwiteite by verskillende volke. Volgens Egiptiese mitologie was dit die god-koning Osiris wat beskawing en die groei van gewasse na Egipte toe gebring het. Hy was vereer as die god van die onderwêreld wat lewe en vrugbaarheid moontlik gemaak het.

$4 \quad$ Hator was ' $n$ komplekse godin wat as moeder, beminde en dogter van die skepper songod opgetree het. Sy was geassosieer met die aandhemel. Sy het vroue help geboorte gee, die dooies gehelp om weer gebore te word en die kosmos gehelp om te herleef. 
Osiris was bestem om sy pa Geb, die aarde, as god-koning op te volg. Uit afguns het Set sy broer Osiris vermoor. Set het sy liggaam in verskeie stukke gesny en regoor die land Egipte verstrooi. Isis, die vrou-suster van Osiris, het met die hulp van ander gode die dele van sy liggaam oor jare gesoek om dit weer bymekaar te maak. Slegs die penis, wat in die Nylrivier gegooi is, kon sy nooit vind nie. ' $\mathrm{n}$ Vis het dit ingesluk. Daarom het sy ' $n$ nuwe geslagsdeel uit klei of hout gemaak en dit gebruik om weer swanger te $\operatorname{raak}^{5}$. Osiris se seksuele krag was so sterk, dat hy Isis daarmee swanger gemaak het om Horus te verwek.

Die oorspronklike penis van Osiris het in die onderwêreld gebly. Daarmee het die Egiptenaars geglo dat hy die land van die dode in ' $n$ ewige bron van vrugbaarheid verander het. Wanneer die lewegewende waters van die Nylrivier jaarliks opgewel het om alles daarrondom te benat, is dit in Egipte beskou as die saad en vog van Osiris, wat lewe bring en gee. Hy het die dood oorwin deur nuwe lewe uit die dood te wek. Hierdie daad spreek van seksualiteit. Ook die belangrike rol wat die alomteenwoordige fallus in die antieke wêreld gespeel het, word hiermee beklemtoon.

Die Mesopotamiese Gilgamesj-epos onderstreep verder die kulturele waarde van seksualiteit wanneer seks as die basiese voorwaarde geld vir die beskaafde menswording van Enkidu - ' $n$ wilde dier-mens, wat ' $\mathrm{n}$ vriend van koning Gilgamesj, koning van Uruk sou word.

Enkidu het saam met die wilde diere geleef. Hierdie onbeskaafde wilde mens moes eers saam met die prostituut Sjamhat seksueel verkeer om beskaaf te raak. ' $n$ Jagter het die prostituut na Enkidu gebring met die opdrag om hom te verlei en na die stad toe te bring. Na ses dae en sewe nagte se seksuele omgang met haar was Enkidu versadig van haar sjarme. Hy is bevry van sy dierlike instinkte as wilde-mens; en daarna het die diere van hom af weggevlug.

5 Hiermee het Isis verskeie rites ter ere van Osiris in die land ingevoer. By die mummifisering van die mans is hul geslagsdele aan die basis afgesny. Hierdie afgesnyde liggaamsdeel is dan kunsmatig verleng, verhard en dan in ' $n$ spesiale vaas bewaar vir verdere seksuele gebruik. 
Hierdie voorbeelde uit Egipte en Sumerië illustreer dat seksualiteit waardeer was vir die waarde wat dit in die lewensruim, kultuur en beskawing indra.

\section{LIEFDE EN SEKS SOMS ONGEREELDE BEDMAATS}

\subsection{Grense was nie so geslote nie}

Seks in die antieke wêreld(e) was nie altyd aan liefde gekoppel nie. Beide seks en liefde was nie noodwendig bindend vir die eg nie. Die aard van die antieke eg-verbintenis, wat soms deur politiese of sosioekonomiese dryfvere tot stand gekom het, het daartoe gelei dat seksualiteit en erotiek waardeer is vir die intrinsieke waarde daarvan. Voortplanting en vrugbaarheid was nie die enigste dryfvere agter seksuele aktiwiteite nie. Daarvan getuig talle verhoedingsvoorskrifte en voorbehoedmiddels uit Egipte.

Vrye liefde en seksuele avonture was egter nie die alternatief in die ou Nabye Ooste nie, omdat seks en liefde nie altyd bedmaats was nie. Sosiale en samelewingsvoorskrifte het bestaan. As mense hierdie reëls of grense sou oorskry, kon hulle sosiale probleme verwag.

Vir die ou Nabye Oosterse samelewing was dit aanvaarbaar dat ' $n$ man buite die eg met ongetroude vroue of prostitute seksueel verkeer het. Die grense van die eg was nie so geslote soos in vandag se wêreld nie. Wanneer ' $n$ man nie by sy eggenote of byvrou seksueel bevredig is nie, was daar drie moontlike verhoudings buite die eg wat deur die ou Nabye-Oosterse samelewings verdra is, naamlik, sakrale prostitusie, profane prostitusie en die verhouding met ' $n$ metgesel (Haag \& Elliger 1998:160):

- Sakrale of heilige prostitusie het in die omgewing van die tempel plaasgevind. Inheemse vroue (en manne) het ' $n$ seksuele diens aan vreemdes gelewer. Daarmee het hulle die tempelskat met hulle seksuele aktiwiteite help aanvul, terwyl hulle seksualiteit om godsdientige redes bedryf het. Ter wille van die godin van liefde en vrugbaarheid het hulle hierdie krag van die lewe aangewakker. Seksualiteit is hiermee aan religieuse motiewe verbind. Vir die Oosterling het dit onder andere beteken dat seksuele omgang tussen mense, die vrugbaarheid wat gode gee, verseker en stimuleer.

- Profane prostitusie is meerendeels deur armes en sosiaalswakkes beoefen. Hierdie vroue was aan bepaalde reëls 
onderworpe en moes soms belasting betaal. Hulle was veral in groot stede en in hawegebiede bedrywig.

- Belangrike manne in die samelewing het dikwels " $n$ vrou gehad, met wie hulle nie net seksueel verkeer het nie, maar wie hulle in die openbaar begelei het. Hierdie metgeselle was meestal opgevoede en gekultiveerde vroue, wat musiek, politiek en filosofie geken het. Hulle het finansiële aansprake op hul begeleidende troetelvaders gemaak, maar daarvoor het hulle begeleiding aan bepaalde behoeftes voldoen.

- Getroude vroue was van die openbare lewe uitgesluit. Hulle hoef nie mooi of slim te wees nie, maar hulle moes bepaalde deugsaamheid hê en handhaaf.

Voorhuwelikse geslagsverkeer was nie in Egipte ontoelaatbaar nie (Fox 2001:25). Geliefdes het hulle later in die eg verbind. Daarom het hulle eers gemeenskaplik saamgebly. 'n Voorbeeld van hierdie jeuglike liefdemakery kom in die volgende gedig voor:

"Hoe mooi is die uur, wat ek saam met jou deurbring!

Die uur gedy tot in ewigheid -

Dit het begin toe ek by jou kom lê het.

In kommer en in vreugde het jy my hart opgehef.

Moet my nie verlaat nie!" (Fox 2001:25).

Egbreuk het plaasgevind wanneer mans met getroude vroue seksuele omgang gehad het. In ou Nabye-Oosterse gemeenskappe is egbreuk slegs van die eggenote, naamlik die vrou se kant gepleeg. Ontrou van ' $n$ eggenote is met swaar strawwe beboet. In Assiriese en oudBabiloniese wetgewing is egbreuksters se neuse afgesny. Hulle is ook soms doodgemaak. Die primêre verantwoordelikhede van ' $n$ wettige eggenote was om legitieme kinders te verwek en om die voortbestaan van die familie te verseker. Egbreuk was nie ' $n$ vergrype aan seksuele moraal nie, maar 'n skending van die eggenoot se eiendomsreg.

In oud Israel was vrye seksuele verkeer van ' $\mathrm{n}$ getroude of ongetroude man met " $n$ ongetroude vrou ook nie problematies nie. Geen beperkinge is op hierdie soort verhouding gestel nie. Nêrens word hierdie seksuele omgang afgekeur nie. 'n Meisie mag egter nie verkrag word nie. Daarvoor het daar ernstige strawwe bestaan (Deut 22:23-29). Verkragting was in Israel ' $\mathrm{n}$ eiendomsdelik. Iemand wat 
hom hieraan skuldig maak, het hom aan die eiendom van ' $\mathrm{n}$ ander man vergryp.

\subsection{Moreel of immoreel?}

Vrae met betrekking tot seksuele moraliteit word moeilik vanuit die antieke samelewings beantwoord. Watter seksuele praktyke was dan nou moreel of immoreel? Behalwe vir ' $n$ aantal taboes, soos seksuele omgang met kinders of diere, asook bloedskande, is daar nie aanduidings van seksuele praktyke wat as immoreel gegeld het nie.

' $\mathrm{n}$ Lys omina (voortekens) uit Mesopotamië in die eerste millennium $\mathrm{vC}$ dui wel op verskillende gevolge wat " $\mathrm{n}$ man op hetero- en homoseksuele dade te wagte kan wees. Daar is geglo dat 'n seksueel aktiewe vrou byvoorbeeld vir " $n$ man ongeluk besorg, terwyl 'n seksueel passiewe vrou vir hom geluk veroorsaak. Verder is gereken dat homoseksuele verkeer goeie belofte vir die toekoms inhou. Daar was dus in die samelewing verskeie gevolge vir verskillende soorte seksuele praktyke. Hierdie is waarskynlik die naaste aanduiding in Mesopotamië van aktiwiteite, wat moreel tot beter seksuele keuses gelei het (Haas 1999:19).

Verder was die ou Nabye-Oosterse wette slegs geïnteresseerd in die seksuele verhouding tussen man en vrou binne die eg. Die oudste wetboek, naamlik die Wetboek van koning Hammurabi (Codex Hammurabi), bevat byvoorbeeld verskeie wette rakende die eg en familiereg (par 127-195), wat vroue en kinders betref (Richardson 2000:81-103), maar geen wet oor die seksualiteit tussen ongetroudes het hierin bestaan nie. Die gevolgtrekking hieruit is: òf daar was nie derglike (geskrewe of ongeskrewe) regulasies nie (wat bykans onmoontlik is), òf die wetgewers het hulle nie daaroor bekommer nie, aangesien dit geen (morele) gevaar vir die volke(re) gemeenskap(pe) ingehou het nie.

\section{BOORDE VOL EROTIESE BEELDE}

\subsection{Om aan die appels te smul tussen die takke}

Soos wingerde in die son lê die dubbelsinnige erotiese metafore wyd gestrooi in die liefdeslirieke ${ }^{6}$, gedigte en ander seksuele beskrywings van die ou Nabye Ooste. Seksualiteit word binne hierdie wêrelde

6 Belangrike voorbeelde van hierdie liefdesgedigte kom uit Egipte (Hallo \& Younger 1997:126-130), Akkad (Hallo \& Younger 1997:445-446) en Sumerië (Hallo \& Younger 1997:540-544). 
meestal subliem voorgestel en eufemisties beskrywe. 'n Kleurvolle en geurige beelde-wêreld word oopgedek. Beelde het soms meer as een betekenis, sodat die seksuele agter die alledaagse verhul lê.

Plante, diere, natuurverskynsels en beelde uit die ou NabyeOosterse 'tuin'-kultuur bied metafore om hierdie aangename lewensgenot van die seksuele bruisend op te dis. Vrugtebome, wingerde, blomme en die wonder van bloeisels in die voorjaar is bekende beskrywings van seksuele genot. Vergeet nie die rol wat granaatappels of appelbome in hierdie verband speel nie. Appels was daar om te eet en te geniet. Wanneer ' $n$ man die liefde van ' $n$ vrou wou wen, moes hy " $n$ besweringspreuk oor 'n granaatappel uitspreek, daarna het die geliefde die appel geëet (vgl Gen 30:1415). Hierby kom nog vele heerlike landbouprodukte soos wyn, olie, heuning, flas, bier, gars en koring - almal beelde om aan te dui hoe mense aan die vrug van liefdesplesier kon smul en dit geniet. Daaraan kan mense hulle vandag nog steeds verkneukel.

Egiptiese liefdesliedere is diep eroties en vertoon ' $n$ sterk ingetoënheid. Sowel die seksuele daad as genitalië word indirek of met metafore beskryf (Fox 2001:25). 'n Geliefde jongman sê oor sy meisie:

“...met haar dye het sy my vasgedruk, met haar brandmerk het sy my opgedruk".

In 'n ander Egiptiese beskrywingslied sê die geliefde:

"Die mond van my suster is 'n lotusknop,

haar borste is liefdesappels,

haar arms is die takke".

Hierdie verliefde wil tussen die takke lê en appels eet. Die lotusblom is ' $n$ primêre metafoor in die liefdesliriek. Die blom verteenwoordig groei, verjonging en nuwe krag. Soos wat hierdie blom uit donker water na vore kom, so groei die liefde uit donker chaos.

In ' $n$ Mesopotamiese gedig word die liefde tussen Isjtar en Dumuzi soos volg geskets wanneer Dumuzi sy geliefde antwoord (Sigrist 2001:19):

"Jong meesteres, die koning wil jou land omploeg!

Mag Dumuzi, die koning, dit vir jou omploeg".

Daarop reageer Isjtar:

"Grawe geen kanaal nie, want ek is jou kanaal 
ploeg geen veld nie, want ek is jou veld

Ploeër, moenie na ' $n$ vogtige aarde soek nie

want ek is jou vogtige aarde".

Uit hierdie lied word vroulike seksualiteit met ' $n$ nat ploegland of waterkanaal verbeeld. Daarin laat die man sy ploeg insak om die vrugbare grond van die aarde om te dolwe. Haar nattigheid en die water druk nie alleen die meisie se seksuele opwinding en opwelling uit nie, maar onderliggend speel haar vrugbaarheid ' $n$ belangrike rol.

Een van die basiese temas in Egiptiese liefdesliedere is wanneer die liefde as ' $n$ vangnet voorgestel word (Fox 2001:23). Die meisie word met 'n voëlnet vergelyk. Sy stel die vangnet vir die voël, simbool van manlike seksuliteit. Een gedig lui soos volg:

"Die klaende stem van die wildegans weerklink,

die lokaas hou dit gevange

so hou jou liefde my ook vas,

ek kan my nie losmaak nie.

Ek gaan my vangnet afhaal,

Maar wat sal my moeder sê -

(sy) na wie ek elke dag buitbelaai huis toe keer?

Vandag het ek geen vangstrik opgestel nie,

jou liefde het my gevang" (Fox 2001:23).

In hierdie gedig is nie alleen die vrou en haar seksualiteit die vangnet nie, maar poëties word die toepassing van die vangnet omgedraai om ook op die krag van die man se liefde te wys.

\section{2 'n Tuin vol blommetjies en bytjies}

Die tuin is ' $n$ heerlike plek om die liefde tot vervulling te bring. Met die dekor-belaaide fauna en flora was dit in die warm, droë en woestynagtige landskappe van die ou Nabye Ooste die ideale beeld om die intiemste liefdesontmoeting privaat, sensueel, intiem en onvergeetlik te maak. Wêreldwyd is die tuin 'n paradys-simbool van onversteurde geluk.

In die Sumeriese, Babiloniese en neo-Assiriese liefdestaal is die tuin die plek waar geliefdes liefdesvreugde geniet. In die skadu's van die bome gee hulle hulleself oor aan die liefde. Die prag van die tuin met al sy vrugte skep meermaal die agtergrond vir die liefde wat hier 
tot bloei kom. Verskeie kere het die liefdesgodin Isjtar verlief geraak op die tuinier, haar geliefde.

In Egiptiese liefdeslirieke is die tuin-metafoor opvallend in die sogenaamde blommeliedere. Die meisie pluk soms blomme, terwyl sy ander kere met die blomme vergelyk word. Blomme sinspeel dikwels op die verskillende geure wat die geliefde vrystel. In een blommelied sê die meisie:

"Ek behoort aan jou soos "n blommeveld,

waarop blomme en welriekende plante groei.

Bekoorlik is die kanaal, wat daardeur vloei,

wat jou hand gegrawe het,

terwyl ons onsself verfris in die Noordewind

'n verruklike plek vir 'n uitstappie,

hand aan hand!" (Fox 2001:24).

Beide die blommeveld en die kanaal is metaforiese beskrywings van vroulike genitalieë, terwyl die 'hand' die manlike geslagsorgaan aandui. Eksplisiete seksualiteit kry daarmee ' $n$ sensualiteit en sagtheid, wat daarby pas.

Die boek Hooglied bevat soortgelyke tuinbeskrywings (Hoogl 4:12-16: 5:1), waar eksplisiete seksualiteit metafories verhuld of by wyse van suggestie verwoord word. Ook in bybelse liefdeslirieke vervul die tuin met sy geurbelaaide flora en fauna ' $n$ soortgelyke funksie. Die fontein met sy nat, borrelende water dui op vroulike seksualiteit. Hierdie metafoor dui op die geliefde of haar genitalieë. So ook het die 'bloeiende tuin' in die Mesopotamiese konteks die geliefde of haar vagina aangedui.

Verskeie metafore binne die antieke wêreld het manlike en vroulike geslagsdele of die geslagsdaad eufemisties versag. Daarmee is bruisende en opwellende liefdesgevoelens vir die erotiese opgewek. Die bloeiseldraende Lactuca plant was die simbool vir skaamhare; die tuin vir die vagina; die vrugte uit die tuin vir die vroulike skaamdele. Daarteenoor was die garsstingel en appelboom aanduidings van die manlike geslagsorgaan (penis), terwyl die koring op die sperma dui.

Vroulike skaamdele staan soms as 'die soete vagina', 'n graf' of 'vogtige plek' bekend. 'n Vergelyking word selfs met die mond gemaak, 'soos haar vagina is haar mond soet'. Die vagina is verder 
'n 'mond van hare', ' $n$ mond van geheime meedeling', "'n mond van lus', 'heuningmond', 'n voëlnessie waaruit die slang uitkom' of ' $n$ skitterende ornament'. Skaamlippe is die 'lippe van heuning' (Haas 1999:131), terwyl die metafoor vir die vogtigheid in die vagina verbeeld is met 'bier' wat mens drink. Uit ander Mesopotamiese literatuur is die klitoris '"n dubbub-voëljie in sy gaatjie', 'die vrugdraende in die tuin' of die 'suiwer kleintongetjie'.

In ' $\mathrm{n}$ Sumeriese dialoog kom die volgende beskrywing voor:

"Die bier is soet,

haar vagina is soet soos haar bier - en haar bier is soet!

En haar vagina is soet soos haar geselsery - en haar bier is soet.

Haar bier is soet, haar bier is soet" (Haas 1999:131).

Fallus metafore en beelde kom wydverspreid in die ou Nabye Ooste voor. In verskeie liefdestekste wens die meisie dat hierdie liggaamsdeel van haar geliefde 'so hard soos tamariskhout' word. Die man se geslagsdeel is verder soos ' $n$ appelboom wat in bloei staan, terwyl die beeld van 'n 'slang wat by sy gat uitkom' op sowel die vroulike skaamdele as die manlike geslagsorgaan dui.

Die volgende lied se beelde spreek vanself. Hierin nooi die meisie haar geliefde uit om haar liefde te kom geniet:

"My wol is die Lactuca (plant), hy sal dit natmaak,

sy is ' $n$ spesiale Lactuca, hy sal dit natmaak

en die $d u b b u b$-voëljie in sy nessie aanraak.

My oppasster het my mooi opgetooi,

Sy het my wol met 'n takbok-kapsel gesny

en sy het dit elegant gekam,

en sy het my 'hy sal kom' gereedgemaak.

Laat hy kom in my wol, die aanmoediging van die Lactuca.

Met my uitnodigende blik

wil ek my broer uitdaag,

wil ek die...broer uitnooi” (Haas 1999:131).

Metafore vir geslagsgemeenskap en orgasme ontbreek nie in Mesopotamiese liefdesliteratuur nie. Met die fallus as ploeg en die skede as akkerbedding word die geslagsdaad konkreet verbeeld deur ploeg-handelinge of selfs wanneer die aarde besproei of natgemaak word. 
Die volgende deel van ' $n$ liefdesgedig dien as illustrasie:

"Die wind sal waai, die tuin sal bewe!

Die wolke sal saampak! Die reëndruppels sal val!

Laat my potensie soos stromende vloedwater wees!

Laat my penis 'n stywe harpsnaar wees,

Sodat dit nie by haar uitgly nie" (Haas 1999:135).

Metafore is onlosmaaklik deel van seksuele en erotiese uitbeeldings in die ou Nabye Ooste. Beelde verhul. Dit versag en suggereer eksplisiete seksualiteit, wat weer aan seksuele vervulling nog ' $\mathrm{n}$ ronder en voller dimensie verleen. Verder verhoog metafore die erotiese kommunikasie van intieme en private aspekte van seksualiteit, sonder om die sekshandelinge banaal voor te stel. Beeldryke beskrywings gee die detail van seksualiteit met groter sensualiteit weer. Genitalieë en seksuele dade kry deur metaforiese beskrywings soos 'tuin', 'aarde bevogtig', 'ploeg', en vele meer, 'n ryke sublimiteit van vele verbeeldingsmoontlikhede.

\section{ANTIEKE TUINE WAS ALTYD VOL APPELBOME}

\subsection{Gode span die harpsnare van die begin af}

In die Jahwegeloof van die Ou Testament ontbreek vroulike godinne asook die seksuele omgang tussen Jahwe en ' $n$ vroulike godinfiguur. Alhoewel die argeologiese ontdekkings by Kuntillet 'Ajrud en Kirbet ' $e l$ Qom in die suide van Israel inskripsies opgelewer het waar "Jahwe en sy Asjera" vir bepaalde seën-handelinge verantwoordelik is, bewys dit nie die verering van ' $n$ vroulike godin in Israel nie. Jahwe word wel as 'n sterk, manlike god uitgebeeld, maar vroulike seksualiteit in die gode-sfeer is feitlik afwesig.

Dit is tog interessant dat seksualiteit voorkom by die Kanaanitiese hoofgod El of 'Ilu, met wie die Israelitiese God Jahwe later identifiseer (Gibson 1977:124-126). Rondom die geboorte van $E l$ se twee kinders Sjagar (Dagbreek) en Sjaliem (Aandskemer) gaan die god uit op die seestrand waar hy twee vroue gewaar, wat op en af beweeg. Sy orgaan (letterlik: hand) groei dan so lank soos 'die vloed' en die see. Dan neem hy die twee vroue, wat op en af beweeg, na sy huis toe. Hy verlei die twee, sodat hulle vir altyd die vroue van El word. Dan volg die volgende beskrywing:

"Hy buig neer, soen hulle lippe,

hulle lippe is soet, soet soos granaatappels. 
Wanneer hy hulle soen, is daar konsepsie;

wanneer hy omhels is daar swangerskap.

Die twee was in barensnood en gee geboorte

aan Sjagar en Sjaliem" (Hallo \& Younger 1997:280-281).

In die allegoriese uitbeelding tussen Jahwe en sy volk speel die metafore van Jahwe as man en Israel as sy vrou ' $n$ belangrike rol. Seksuele sinspelings wat aspekte van hierdie verhouding tussen God en sy volk belig, kom aan die orde (Hos 1-3; Eseg 16; 23): hierdie seksualiteit word subliem en eufemisties uitgebeeld. Dit het tot gevolg gehad dat die seksualiteit van God vir Jode en Christene ' $n$ taboe-tema in die geskiedenis geword het.

As monoteïstiese God was Jahwe 'n manlike God. Hy het geen vrou of kind gehad nie. Verder was Hy 'n manlike kryger-god wat sy volk gelei en gered het. In die geskiedenis het Hy hoofsaaklik met mans onderhandel. Van hulle het Hy absolute gehoorsaamheid aan Hom verwag. Die bestaan van gode en godinne naas Hom verdra Hy glad nie (Deut 6:4).

Onder Israel se bure in die ou Nabye Ooste was dit anders. Gode en godinne was seksueel aktief. Hulle het saam met mekaar gelewe, getrou en kinders gekry. Daarom is seksualiteit op verskeie maniere in die godsdienstige lewe van politeïstiese volke teenwoordig. Natuurkragte en die ritme in seisoene is gekoppel aan gode, wat vir lewe en vrugbaarheid van plante, mense en diere verantwoordelik was. Die gode het hierdie kragte gepersonifieer. Deur hulle krag en toedoen het lewe en vrugbaarheid ontstaan.

In Babilonië het die koning aan die begin van die Nuwejaar met ' $\mathrm{n}$ spesiale nugig priesteres in die tempel van die god Marduk 'n 'heilige huwelik' gesluit. Deur rituele van seksuele handelinge het die koning simbolies seën vir die land in die toekomstige jaar verseker. In Kanaan was daar ook verskillende seksuele rites, gebruike en kultusse, wat met vrugbaarheid saamgehang het. Baäl, die god van vrugbaarheid, is deur ' $n$ jong bul versimboliseer. Sy vrou was Asjera. Teen rites van hierdie kultus het Elia en Hosea in die Noordryk van Israel geprotesteer.

Ook in Egipte speel seksualiteit ' $\mathrm{n}$ rol by die totstandkoming van die kosmos. Die antieke godetuine was altyd vol appelbome. Die krag van die lewe het uit die lendene van die gode gevloei. Daarom 
word kosmogoniese (skepping van die wêreld) handelinge gereeld aan seksuele dade van gode en godinne gekoppel.

Ter illustrasie van seksuele aktiwiteite wat tot die geboorte of totstandkoming van die wêreld en ander kosmiese magte aanleiding gegee het, neem ons die Egiptiese konteks. Met die storting van sy eie saad deur middel van masturbasie het Atum, die songod, aanleiding gegee tot die verwekking van drie ander gode (Wyatt 2001:57-58). Hierdie patroon kom ook by ander Egiptiese gode soos Re, Amenafet, en Min voor. Op dieselfde manier verwek die wesSemitiese god El twee dogters, met wie hy trou om ander gode by hulle te verwek.

In nog een van die Egiptiese skeppingsmites ontstaan die kosmos deur die paring of seksuele omgang tussen hemel en aarde, wat deur die gode Geb (aarde) en Nut (hemel) verteenwoordig word (Bishop 2004:33). In teenstelling met ander ou Nabye-Oosterse skeppingsvoorstellings is die aarde manlik en die hemel vroulik. Normaalweg word die aarde as vroulik en die hemel as manlik binne die Kanaänities-Mesopotamiese mitologieë voorgestel, omdat die aarde haar vrugbaarheid met vele gewasse, oeste, plante en vrugte, ja, die nuwe lewe uit die natuur bevestig.

Nie net die kosmos self nie, maar ook ander natuur- en lewenskragte binne die skepping ontstaan volgens Egiptiese mitologie vanweë seksuele aktiwiteite van die gode. Die geboorte van gode-kinders is die direkte gevolg van seksuele omgang tussen die gode. Shu (lug en sonlig) en Tefnut (vogtigheid) is gebore ná die seksuele omgang tussen $R e$, die songod, en sy eerste geslagsgenoot (partner), naamlik sy hand. Uit hierdie seksuele daad is Nut en Geb, die personifikasie van hemel en aarde, gebore. Masturbasie word hiermee veronderstel. Seksuele omgang gee verder aanleiding tot die geboorte van nog gode. So speel seksualiteit dus ' $n$ definitiewe rol in die totstandkoming van sowel die kosmos as ander natuur- of lewenskragte binne sekere streke van die ou Nabye Ooste.

\subsection{Godin van seksualiteit - Isjtar (Inanna)}

Een van die belangrike invalshoeke op die tema van seksualiteit in die ou Nabye Ooste is om met die Sumeriese hemelgodin van seksualiteit, Inanna, of haar Babiloniese eweknie, Isjtar, kennis te maak. Sy was tegelyk godin van liefde en oorlog. Haar naam en reputasie het ver oor die grense van Mesopotamië gestrek. As 
bekende godin in die antieke wêreld het sy bestaan as Astarte, Anat, Artemis, en Afrodite.

Ná die skepping het die gode die kosmos georden. Bepaalde lewensterreine is in die daaropvolgende gebeure aan bepaalde gode toegeken. In Mesopotamië het die god van wysheid Enki aan Inanna verskeie heerskapsterreine toevertrou. Veral die magsgebiede van seksualiteit en prostitusie is aan haar gegee. Sy was verantwoordelik vir lewenskrag en voortplanting van mens(e), dier(e) en gewasse. Sonder haar was alle lewe bedreig. Die tweeledige kragte van oorlog en liefde het aan Inanna onweerstaanbare mag verleen. Sy het in haarself die magte van hartstog, wildheid, anargie, onberekenbaarheid, aggressiwiteit en ekstase omgedra.

Inanna se astrale verskyningsvorm was sedert die vroegste tye die Venusster. As oorlogsgodin word sy meestal met wapens voorgestel, maar as naakte liefdesgodin verskyn sy op verskillende maniere. Soms staan sy as gevleuelde godin op twee steenbokke, terwyl sy ander kere staande op 'n leeu uitgebeeld word. As liefdegodin is sy die aggressiewe godin van seksuele vitaliteit, wat vir vrugbaarheid verantwoordelik is.

Inanna se besondere betekenis as godin tree na vore in ' $n$ mite waar sy die onderwêreld (doderyk) besoek. Sodra sy daar aankom, verdwyn seksualiteit van die aarde. Dan kom die bestaan van alle lewe op aarde onder bedreiging. Haar besoek aan die onderwêreld en uiteindelike terugkeer staan in noue verband met die antieke Oosterlinge se verstaan van die jaarlikse seisoenwisselinge. Op hierdie manier vergestalt Inanna verder die ervaring dat die kiem van bedreiging en ondergang selfs in die hoogste vorm van beskawing bestaan.

\subsection{Die liefde blom tussen Inanna (Isjtar) en Dumuzi}

Die geliefde en metgesel van die liefdesgodin Inanna was Dumuzi ("troue seun"), wat veral in Babiloniese, maar ook in Hebreeuse en Aramese Maart-tradisies as Tammuz bekend staan. In die meeste van 38 Sumeriese liefdesliedere tree beide as vrugbaarheidsgode op. In hierdie liedere kom die liefde tussen Inanna en Dumuzi tot hoogbloei. Sommige Mesopotamiese literêre tradisies skilder Dumuzi as ' $\mathrm{n}$ herder, terwyl ander hom as koning van $\mathrm{Uruk}^{7}$

7 Uruk is die stad in Mesopotamië waar die held van die Gilgamesj-epos ook koning was. 
voorstel. Enersyds is hy die beminde van Inanna (Isjtar), maar andersyds is hy die god wat aan die begin van die nuwe jaar uit die onderwêreld (dood) na die lewe toe terugkeer.

Die liefdesgedigte besing die hofmakery tussen Dumuzi en Inanna; hoedat hulle in die eg verbind gaan word met allerlei seremonies; asook hoe hul liefde tot liggaamlike vervulling kom. Dumuzi se hofmakery word eerder van Inanna uitgelok. Sy beskryf haar seksuele wense en begeertes, terwyl hy daarop reageer.

Alhoewel daar literêre aanduidings in Mesopotamië is dat die aktiewe rol van die vrou in seksualiteit vir die man ongeluk bring, gaan die inisiatief in die Inanna-Dumuzi liefdeslirieke eerder van die vrou uit. Hiermee word die aktiewe rol van die vrou in seksualiteit nie uitgesluit nie. Normaalweg het " $n$ passiewe man vir "n maand lank geen beskermgod gehad nie, hy was as onrein beskou en sy god sou nie sy gebede verhoor nie. Daarmee is die aktiewe manlike rol in seksualiteit binne die Mesopotamiese kulture aangemoedig. Ook in Egipte is die seksueel aktiewe rol van die vrou aangeteken. Een inskripsie wys dat ' $n$ vrou nie vir die man terugstaan nie. ' $n$ Dame wat ' $\mathrm{n}$ man beter wou leer ken, staan op, neem hom aan die hand en sê: "Kom laat ons tog "n uurtjie bed toe gaan, dit sal vir jou aangenaam wees..." (Trassard ea 2005:24).

In Mesopotamië het die invloed van Inanna en Dumuzi se voorbeeld van ' $n$ gode-huwelik op vrugbaarheidsrituele, 'heiligehuwelike' en tempelprostitusie ' $n$ belangrike rol gespeel.

\section{4 'n 'Heilige huwelik'}

In die ou Nabye Ooste was daar verskeie rituele wat vrugbaarheid aangemoedig het. So het dit gebeur dat ' $n$ boer baie keer met sy vrou op die landerye geslaap (seksueel verkeer) het om groeikragte vir ' $n$ goeie oes te stimuleer en te verseker.

Godehuwelike soos dié van Inanna en Dumuzi is ' $\mathrm{n}$ voorbeeld waar Sumeriese konings op die dag van nuwejaar in die kultus ' $n$ 'heilige huwelik' ${ }^{8}$ met ' $\mathrm{n}$ vrou, gewoonlik ' $\mathrm{n}$ priesteres, aangegaan

8 Die begrip 'heilige huwelik' is ' $\mathrm{n}$ tegniese term vir hieros gamos, en het op die huwelik tussen Zeus (hemel) en Hera (aarde) in die gode-mite gedui. Zeus se reën het Hera bevrug. In die godsdienswetenskap is die begrip uitgebrei met betrekking tot seksuele rituele wat vrugbaarheid bevorder het. Mesopotamiese konings het by die tempels met onbekende vroue seksueel 
het (Winter 1983:313-368; Haas 1999:122-126; Sigrist 2001:16-18). Hierdie simboliese handeling is voltrek ten einde die vrugbaarheid van velde, tuine en boomplantasies te bevorder en te verseker. Die ritueel beteken nie letterlik dat die deelnemers hulle in die eg verbind nie, maar dit bly ' $\mathrm{n}$ simboliese handeling tussen die koning en ' $\mathrm{n}$ nugig priesteres. Die koning verteenwoordig die sterwende en weer-opgestane vegetasiegod, Dumuzi, en beliggaam daarmee die siklus van seisoene. Hy sterf simbolies soos Dumuzi ten tye van droogte of aan die einde van die oujaar, maar staan simbolies aan die begin van die nuwe jaar of nuwe vegetasie weer tot lewe op.

Die hoogtepunt van die heilige huwelik is wanneer die koning met die verteenwoordiger van die godin, 'n priesteres, seksueel verenig. ' $n$ Feesoptog word deur die kultiese personeel by hierdie geleentheid gehou. Hulle prys die godin van liefde, Inanna. Sy word in beide haar verskyningsvorme, die oggend- en aandster, lof toegeswaai.

As oggendster is sy die godin van oorlog. Vooraan die feesoptog maak die musikante musiek. Agter hulle volg verskeie groepe mense. Daar was jong mans met jukke op hulle nek wat gevangenes voorgestel het. Ou en jong dames vermom hulle as prostitute. Ook manlike prostitute het deel van die prosessie uitgemaak. Tydens ' $n$ bloedige geveg verwond kultus-personeel mekaar liggaamlik met messe sodat die godin medelye met hulle kan toon.

As aandster dui Inanna die einde van die dag se werk aan. Egpare gaan dan bed toe en wy hulle aan mekaar. In hulle slaap gaan staan hulle voor Inanna, wat na hulle wense en begeertes luister. Sy oordeel dan tussen goed en sleg, en besluit wat hulle lot is. Op die tweede dag van die fees bring mense offers en geniet 'n kultiese maaltyd. Die hoogtepunt van die fees was die voltrekking van die 'heilige huwelik' tussen die koning en sy bruid. Sy was die gestalte van die godin Inanna. Almal kom buig voor haar. Ná die seksuele vereniging tussen die koning en sy bruid sluit ' $n$ voorbereide feesmaal die seremonie af.

Die bruidsbed is geurvol voorberei met kruie en parfuum. ' $n$ Standbeeld van Inanna is eers ritueel gewas, waarna die 'goddelike'

verkeer in navolging van die gode-mites, ter wille van die seën wat dit vir die koning, volk, kuddes en land ingehou het. 
seksuele daad op die bed plaasgevind het. Hierdie geslagsdaad simboliseer die moontlikheid van nuwe lewe. Die seksdaad dui op 'n nuutskepping. In die sentrum van die ritueel staan egter die lotsbepaling van die koning. Dit vra na die rol en lot van die koning vir die komende nuwejaar. Met sy jaarlikse troonsbestyging tydens hierdie nuwejaarsfees is die koning se charisma versterk. Hierdie charisma waarborg seën en voorspoed vir die land vir die jaar wat voorlê. Deur die krag van haar skoot gee Inanna, die godin van liefde, krag en aangename heerskappy aan die koning, met seënryke gevolge.

Die gode-verhaal van Inanna en Dumuzi verteenwoordig die gees van denke oor seksualiteit in die ou Nabye Ooste. Dit bevestig die feit dat seksualiteit as ' $n$ religieuse mag deur oosterlinge beskou is. Menslike en goddelike seksualiteit was eng aan mekaar verbonde. Die krag van die seksuele het nuwe lewensmoontlikhede vir die winter van die lewe ontsluit. Dit het gegeld vir die koning, vir die land, en vir sy mense.

\subsection{Rooiligte oral by die tempel(s)}

Tempels in die ou Nabye Ooste was rooiliggebied. Daarvoor het die liefdespaar, Inanna en Dumuzi, gesorg. Die gode-mite van die 'heilige huwelik', is onder die gewone bevolking gedemokratiseer. Nie net die koning en sy nugig priesteres nie, maar ook die volk het in die lewenskrag van seksualiteit gedeel. Hoe het dit gebeur? By die tempel(s) het vroue en/of priesteresse die liefde met liggaam (en siel) aangewakker. Prostitusie het heelwaarskynlik hoogty binne en buite die tempel(s) gevier. Onderskeid tussen heilige (sakrale) en profane prostitusie is egter nie altyd so duidelik nie.

Verskeie antieke tekste het die godin van liefde, Inanna, aan prostitusie verbind. In sommige beskrywings funksioneer sy as prostituut, terwyl sy haarself in ander as prostituut aandui. In een godsdienstige teks sê sy:

"Ek is inderdaad ' $\mathrm{n}$ karkid prostituut

iemand wat die penis ken" (Haas 1999:43).

Prostitusie was aan die tempels van Inanna (Isjtar) gekoppel. Daar het vroue hulle in diens van die liefdesgodin gewy om godsdienstige of profane redes. Veral arm vroue, en later slavinne is hierby betrek. In Mesopotamië was die vroue in diens van Inanna (Isjtar) en in Sirië-Palestina het hulle Astarte of Asjera gedien. Sowel meisies as jongmans was by hierdie aktiwiteite betrokke. 'n Gedenkplaat uit 
Assur in die 13de eeu vC illustreer die seksuele omgang tussen ' $n$ man en vrou op ' $n$ offeraltaar. Alhoewel daar " $n$ meer verdraagsame houding teenoor profane prositusie in Israel aanwesig was ${ }^{9}$, dui die polemiek teen kultiese prostitusie in die Ou Testament daarop dat Asjera ' $\mathrm{n}$ konkurrent vir die Jahwe geloof was (Deut 23:18fev; 2 Kon 23:6-7). Enige teken van toewyding aan haar het godsdienstige afvalligheid van die God Jahwe beteken.

Alhoewel nie almal daarmee saamstem nie, het die opmerkings van Herodotus, die Griekse geskiedskrywer (ongeveer $480 \mathrm{vC}$ ), gesorg vir ' $n$ stereotipe beeld oor kultus prostitusie in Mesopotamië. Hy het daarop gewys dat elke Babiloniese vrou eenmaal in haar lewe haarself (seksueel) by die tempel aan die godin Afrodite wy. Sy het by die tempel gaan sit en haar aan ' $n$ vreemde man oorgegee. Hierdie invloed van Herodotus het die seksuele aktiwiteite by die kultus tot ' $\mathrm{n}$ dogma verhef. Ook die skerp Ou-Testamentiese veroordeling van kultiese aktiwiteite met seksuele ondertone skep ' $n$ beeld van intense en verhoogde seksualiteit by die religieuse toewyding aan gode onder Israel se bure (Eks 34:15ev; Lev 18:2430; 19:29; Num 25:1ev; Hos 4:13ev; ea).

Die liefdesgodin Inanna het 'n groot gevolg van liefdesdienaresse gehad. Naas die vroue wat om godsdienstige en profane redes by die tempels seksueel aktief was, kan die res van Inanna se gevolg in verskillende kategorieë ingedeel word.

- Daar was die nugig priesteresse. Hulle het deur die simboliese ritueel van die 'heilige huwelik' in die plek van die liefdesgodin met die koning seksueel verkeer. Vroue in hierdie kategorie was ongetroud en het as vroedvrou opgetree.

- Dan was daar die lukur-vroue. Hulle was hoogs gesiene, ryk minnaresse van die koning, wie se seuns die koning se troonopvolger kon word.

- Karkid-prostitute het in die omgewing van die hawe diens gedoen. Hierdie vroue was kinderloos.

- Verder was daar die nadiātu vroue, wat nou aan die tempel verbonde was. Hulle was besondere heilige vroue, wat van onheilige dinge weggehou is.

9 Vergelyk die verhale van Ragab (Jos 2), Tamar (Gen 38), die moeder van Jefta (Rigt 11:1) en Simson (Rigt 16:12). 
- Harimtu-prostitute was afgesonderde meisies wat in ' $n$ tempelbordeel gewerk het.

- Die qadšātu prostitute kon trou, hulle het oor eiendom beskik, en het kinders gehad. Ongetroude meisies van hierdie groep kon kinders aanneem.

- Die kalmašītu(m) of nubar prostitute was aan ' $n$ bepaalde god gewy. Hulle kon trou en kinders kry, maar het nie dieselfde aansien as die qadšătu en nadiātu vroue geniet nie. Getroude vroue was spesiaal aan die Babiloniese god Marduk gewy.

Uit hierdie veelvoud van liefdesdienaresse is dit duidelik dat die invloed van die godin Inanna (Isjtar) ' $n$ belangrike rol in Mesopotamië gespeel het om seksuele vervulling in die samelewing te bewerkstellig ${ }^{10}$. Die krag van seks het deur die verskillende rolle van die liefdesdienares nuwe lewe onder die volke gewek en aangemoedig. Dit het krag en lewensvreugde geskep, wat nodig is om die liefde tot vervulling te bring.

\section{AFLOOP}

Uit die ou Nabye Ooste was seksualiteit en erotiek, net soos eet of drink, deel van die lewe. Die mens is beskou as ' $n$ geheel sonder om hom/haar in liggaam en siel te verdeel. Daarom was seksualiteit deel van die profane én godsdienstige sfere van die lewe. Seksualiteit en godsdiens was eng verbonde. Talle godeverhale, asook die aktiewe rol wat seksualiteit in die kultusse en aktiwiteite van tempelpersoneel gespeel het, bevestig dit.

Seksualiteit was vervleg met die lewe in al sy verskillende fasette. Nie alleen het die seksuele tot lewe aanleiding gegee nie, maar dit was uitdrukking van die lewe self. In seksuele aktiwiteite en beskrywings van die antieke is die seksuele geassosieer met krag, vrugbaarheid, liggaamlike en sinlike genot, lewensvreugde, lewenssin, opwinding en hoop.

Wat in die Inanna-Dumuzi verhale sy oorsprong het, en wat in die simboliese ritueel van die 'heilige huwelik' tydens die jaarlikse Nuwejaarsfees in Babilonië voltrek is, was nie net gedemokratiseer in die antieke wêreld nie, maar wat simbolies daarmee uitgedruk is,

10 Abusch (1999:452-456) gee 'n beknopte geskiedenis van hierdie godin asook hoe sy binne die Mesopotamiese kultuurruimte ontwikkel het as godin van liefde en oorlog. 
is vandag steeds geldig: Wanneer die seksdaad voltrek word, sterf die 'ek' aan hom/haarself. Deur die oorgawe en blootstelling aan die 'ander' steek die 'ek' die grense van die self verby. By die voltooiing van hierdie gemeenskap keer die 'ek' weer terug na die sagte rus van 'n vervulde 'self', vol krag en lewensvreugde. Die 'ek' keer dan vervuld terug na sy eie wêreld wat nuut herlaai is met die goddelike vonk en skoonheid van ' $n$ transendente dinamiek. Daarmee skep seksualiteit hoop, krag en nuwe lewe in ' $n$ immerdoodsbedreigende-lewenslandskap.

\section{Literatuurverwysings}

Abusch, T 1999. Ishtar, in: Van der Toorn K, Becking B, \& Van der Horst P (eds), Dictionary of Deities and Demons in the Bible. Leiden/ Boston/ Köln: Brill, 452-456.

Berlejung, A 2001. Liebe und Eros im Kulturraum des Vorderen Orients. Die Liebenden sind die Götter gleich, in: Frevler, C (Hg), Liebe und Eros. Welt und Umwelt der Bibel 21/6 (2001), 2-7.

Bishop, C 2004. Seksualiteit en spiritualiteit. Ekstase, rituele en taboes. Groningen: Textcase.

Caubet, A 2001. Vom Schmuck und Sich Schmucken. Die Waffen der Verführung, in: Frevler, C (Hg), Liebe und Eros. Welt und Umwelt der Bibel 21/6 (2001), 9-12.

Fox, M 2001. Die Liebeslyrik im alten Ägypten. Deine Liebe ist ein berauchendes Getränk, in: Frevler, $\mathrm{C}(\mathrm{Hg})$, Liebe und Eros. Welt und Umwelt der Bibel 21/6 (2001), 21-25.

Frevel, C \& Wischmeyer, O 2003. Menschsein. Perspektiven des Alten und Neuen Testaments (NEB). Würzburg: Echter Verlag.

Gibson, J C L 1977. Canaanite myths and legends. Edinburgh: T \& T Clark.

Haag, H \& Elliger, K 1998. Zur Liebe befreit. Sexualität in der Bibel und heute. Zürich/Düsseldorf: Benziger.

Haas, V 1999. Babylonischer Liebesgarten. Erotik und Sexualität im Alten Orient. München: $\mathrm{CH}$ Beck.

Hallo, W W \& Younger, K L 1997. The context of Scripture. Canonical compositions from the biblical world. Volume I. Leiden/ New York/ Köln.

Richardson, M E J 2000. Hammurabi's laws. Text, translation and glossary. London/ New York: T \& T Clark.

Sigrist, M 2001. Die Liebeslyrik in Mesopotamien. “...du bist wahrhaftig mein Geliebter", in: Frevler, C (Hg), Liebe und Eros. Welt und Umwelt der Bibel 21/6 (2001), 15-20. 
Trassard, F, Antérion, D, \& Thomaso, R 2005. Leben im alten Ägypten. Übersetzt von Isa Odenhardt-Donvez. Stuttgart: Konrad Theis Verlag.

Winter, U 1983. Frau und Göttin. Exegetische und ikonographische Studien zum Weiblichen Gottesbild im Alten Testament und in dessen Umwelt. Göttingen: Vandenhoeck \& Ruprecht.

Wyatt, N 2001. Space and time in the religious life of the near East. Sheffield: Sheffield academic press. 